\title{
Cloning and Expression of Tomato Leaf Curl Virus Coat Protein Gene in E. coli
}

\author{
S.H. Honnesh*, M.S. Patil, Narayan Moger, V.P. Savalgi, L.S. Rashmi and Ratna Bergi \\ Department of Biotechnology, College of Agriculture, Dharwad University of Agricultural \\ Sciences, Dharawad-580005, Karnataka, India \\ *Corresponding author
}

\begin{abstract}
A B S T R A C T
Tomato leaf curl virus (ToLCV) is a major Geminivirus which cause serious loss to tomato production in tropical and subtropical regions of the world. Hence, considered as major constraint to tomato cultivation. In the present study ToLCV coat protein gene was cloned and expressed using recombinant DNA technology approach. The ToLCV infected tomato leaf samples were collected from tomato fields near Krishi Vigyan Kendra, Dharwad. Further, the total DNA from ToLCV infected tomato leaf sample was isolated by following CTAB protocol. An 786 bp PCR product containing coat protein coding region of ToLCV was amplified using ToLCVCP (forward) and ToLCVCP (reverse) primers and the amplified product was cloned into the pTZ57R/T and further sub-cloned in to the pQE30. After transformation into JM109 and M15 cells the clones were confirmed through PCR and sequencing. Amplification with expected size of $786 \mathrm{bp}$ and homology with other isolate showed integrity of the clone. Further, the coat protein was expressed by inducing with $1 \mathrm{mM}$ IPTG at $3 \mathrm{hr}$ after induction with. The expressed protein was analyzed through sodium-dodecyl sulphate-Poly acrylamide gel electrophoresis (SDS-PAGE). A band of 31 $\mathrm{kDa}$ on the gel confirmed that coat protein was really fused to the $6 \mathrm{X}$ His-tag. Further, $1.34 \mathrm{mg} / 100 \mathrm{ml}$ of the coat protein was purified using His-tag purification kit (Genei).
\end{abstract}

Keywords

Geminivirus,

Recombinant coat protein, TA cloning,

His-tag purification

Article Info

Accepted:

04 March 2018

Available Online:

10 April 2018

\section{Introduction}

Tomato (Lycopersicon esculentum L.) is one of the most widely grown vegetable crops and popular due to its high nutritive value, taste and versatile use (Solieman et al., 2013). In 2015, global production of tomato was 16.38 million tonnes (MT) with an area of 0.0643 million hectares (mha) (NHB, 2015). Tomato is susceptible to more than 200 diseases. However, there are 40 viruses reported. Among these viruses, Tomato leaf curl virus (ToLCV) is a major Geminivirus which cause serious loss to tomato production in tropical and subtropical regions of the world. Hence, considered as major constraint to tomato cultivation. Geminiviruses are not transmitted through seeds, whereas many are grafttransmissible and some are mechanically (sap) transmissible. Plants infected with geminiviruses show a wide range of symptoms including curling, puckering, mosaic cupping, reduced plant growth and bushy appearance (Reddy et al., 2010). Other symptoms include leaf streaking and striations in monocotiledonous plants, leaf crumpling, 
distortion, golden-light green-yellow mosaic/mottle, interveinal yellowing, yellow spots, and vein swelling, purpling, and yellowing in dicotyledonous plants (InoueNagata et al., 2016).

Geminiviruses comprise a biologically and genetically diverse family (Geminiviridae) of viruses that share the following characteristics: a twinned quasi-icosahedral virus particle (virion) that measures $\sim 18$ X 30 nanometers and a small circular singlestranded DNA genome of 2.9- 5.2 kilobases $(\mathrm{kb})$. The family name is derived from the distinctive twinned virions (the Latin word gemini means twin). Based upon genome structure, phylogenetic relationships, insect vector and host range, seven genera have been recognized: Begomovirus, Mastrevirus, Curtovirus, Topocuvirus, Becurtovirus, Turncurtovirus and Eragrovirus (Brown et al., 2012). In nature, geminiviruses are transmitted by phloem-feeding insects, including various species of leafhoppers, a treehopper and whiteflies of the species Bemisia tabaci.

The aim of this work is to express ToLCV coat protein in E. coli and to get purified recombinant protein by His-tag purification using recombinant DNA technology approach.

\section{Materials and Methods}

\section{Sample collection}

The ToLCV infected and healthy tomato leaf samples were collected from tomato fields of Krishi Vigyana Kendra, Dharwad in the month of June 2016.

\section{Total DNA isolation}

The total DNA from ToLCV infected tomato leaf sample was isolated by following CTAB protocol. Two grams of leaf sample was ground in liquid nitrogen to a fine powder and transferred quickly to centrifuge tube containing pre-warmed extraction buffer $(0.1$ $M$ Tris base, $0.05 \mathrm{M}$ EDTA, $0.1 \mathrm{M} \mathrm{NaCl}, 2 \%$ CTAB, $0.1 \%$ mercaptoethanol, $0.1 \%$ PVP) was immediately added to centrifuge tubes and kept in $65{ }^{0} \mathrm{C}$ water bath for 10-15 min with intermittent mixing. After cooling to room temperature, equal volumes of chloroform: isoamylalcohol (24:1) was added and mixed by inverting. It was centrifuged at $10,000 \mathrm{rpm}$ for $10 \mathrm{~min}$ at $4{ }^{0} \mathrm{C}$. The supernatant was taken into fresh tube and equal volume of chilled isopropanol was added and gently mixed. It was kept at $-20{ }^{\circ} \mathrm{C}$ for $2 \mathrm{hrs}$ and then the DNA was pelleted at $15,000 \mathrm{rpm}$ for $10 \mathrm{~min}$. The pellet was washed with 70 per cent ethyl alcohol, air dried, dissolved in $500 \mu \mathrm{l}$ of $\mathrm{T}_{10} \mathrm{E}_{1}$ with $5 \mu \mathrm{l}$ of RNase $(10 \mathrm{mg} / \mathrm{ml})$ and incubated at $37{ }^{\circ} \mathrm{C}$ for $1 \mathrm{hr}$. The DNA was purified by adding equal volume of phenol: chloroform: isoamyl alcohol (25:24:1) and centrifuged at 10,000 rpm for $10 \mathrm{~min}$ at $4{ }^{0} \mathrm{C}$. The aqueous phase was collected and equal volume of chloroform: isoamyl alcohol (24:1) was added and centrifuged at 15,000 rpm for $10 \mathrm{~min}$ at 4 ${ }^{0} \mathrm{C}$. To the supernatant $1 / 10$ th volume of $3 \mathrm{M}$ sodium acetate and twice the volume of chilled ethanol were added, left for $30 \mathrm{~min}$ at room temperature and then centrifuged. After discarding the supernatant, the pellet was washed with 70 per cent alcohol, air-dried and dissolved in $100 \mu \mathrm{l}$ of $\mathrm{T}_{10} \mathrm{E}_{1}$. Total DNA isolated was quantified by spectrophotometeric method as given by Sambrook and Russel (2001).

\section{Primer designing}

The Coding sequence of ToLCV-CP gene was retrieved from NCBI database. Using vector NTI software gene specific primers were designed TOLCV-CP (forward) - 5, ATC GGA TCC TCC AAA ACT GAA GCG GTT 3', ToLCV-CP (reverse) - 5' ATT AAG CTT GTT GCG CAT ACC CAG GAG AG 3'. 
Restriction sites BamHI and SalI were introduced at 5' end of forward and reverse primers respectively and spacer nucleotides were added before restriction sites. The designed primers were synthesized at SigmaAldrich chemicals Pvt. Ltd., Bangalore. The designed sequence of primers is as follows.

\section{PCR amplification of ToLCV-CP gene}

The amplification of ToLCV-CP was carried out using thermal cycler at $94.0{ }^{0} \mathrm{C}$ initial denaturation followed by 35 cycles of denaturation at $94.0{ }^{0} \mathrm{C}$ for $1.0 \mathrm{~min}$, annealing at $60.0{ }^{\circ} \mathrm{C}$ for $1.0 \mathrm{~min}$, extension at $72.0{ }^{\circ} \mathrm{C}$ for $1.0 \mathrm{~min}$, and final extension at $72.0{ }^{0} \mathrm{C}$ for 10 $\min$.

\section{Cloning of ToLCV-CP gene}

The PCR-amplified TOLCV-CP gene was cloned in $E$. coli into pTZ57R/T. All ligation reactions were incubated overnight at $16{ }^{\circ} \mathrm{C}$ and contained equi-molar amounts of PCR product (gene) and vector DNAs. Ligations were conducted using $300 \mathrm{mM}$ Tris- $\mathrm{Cl}$, pH 7.8, $100 \mathrm{mM} \mathrm{MgCl} 2,100 \mathrm{mM}$ DTT, $10 \mathrm{mM}$ ATP and 3 units/ $\mu 1$ T4DNA Ligase. To each $50 \mu$ competent E.coli DH5 $\alpha$ cells, $2 \mu 1$ of ligation mixture was added and mixed gently by tapping.

Tubes were incubated on ice for $30 \mathrm{~min}$, then heat shocked at $42{ }^{0} \mathrm{C}$ for $45-50$ seconds and placed again on ice for $2 \mathrm{~min}$. To each transformation mix, $950 \mu$ of Luria broth medium (tryptone $10 \mathrm{~g} / \mathrm{lit}$, yeast extract $5 \mathrm{~g} / \mathrm{lit}$, sodium chloride $5 \mathrm{~g} / \mathrm{lit}$, agar $18 \mathrm{~g} / \mathrm{lit}$ ) was added and the tubes were incubated at $37{ }^{\circ} \mathrm{C}$ for $1.5 \mathrm{hr}$ with $180 \mathrm{rpm}$ shaking. From each transformation tube, $100 \mu$ were plated on LB plates containing ampicillin $(50 \mu \mathrm{g} / \mathrm{ml})$. Plates were inverted and placed in a $37{ }^{\circ} \mathrm{C}$ incubator overnight. Positive clones were confirmed using blue/white colony screening and restriction digestion.

\section{Sequencing and sequence based analysis}

The restriction confirmed clone (pTHMN15) was sequenced using universal M13 forward and reverse primers. Sequences were processed to remove the vector contamination by using BioEdit software. Further, the homology search was done with BLAST algorithm available at http://www.ncbi.nih.gov.

\section{Expression of ToLCV-CP fusion proteins in E. Coli}

The ToLCV-CP gene was restriction digested from pTZ57R/T using restriction enzymes BamH1 and SalI. The gel purified 786 bp amplicon was ligated into pQE30 (Qiagen). Protein expression in pQE30 was controlled through a double lac operator system and is induced by addition of $1 \mathrm{mM}$ IPTG. Recombinant plasmids containing the inserted PCR fragment were validated by restriction analysis and PCR to confirm the integrity of the cloned DNA. In this way the viral DNA sequence was inserted in frame downstream of the $6 x$ Hist-protein.

\section{His-tag fusion protein purification}

Recombinant protein expressed was purified using 6X His-tag purification kit (Genei cat\# KT65) purified protein was subjected to SDS polyacrylamide gel electrophoresis. The TOLCV-CP gene was sequenced to confirm the integrity of the insert.

\section{Results and Discussion}

The most commonly used diagnostic tool for ToLCV is enzyme-linked immunosorbent assay, which is dependent on the availability of highly specific antibody to differentiate the viruses. By using the recombinant technology expressing the $\mathrm{CP}$ gene in $E$. coli provides the ability to obtain large amount of protein which 
can be used for range of studies (Ramesh, 2010). The expression of recombinant ToLCV-CP was induced by addition of IPTG to a final concentration of $1 \mathrm{mM}$ at $37{ }^{0} \mathrm{C}$ for 4 hr. Expressed fusion proteins were easily purified from bacterial lysates by affinity chromatography using Ni-NTA resin (Devaraja et al., 2004). ToLCV coat protein gene was cloned into prokaryotic expression vector pET28a. The clone was transformed into E. coli BL21, induced by IPTG to produce the target protein. Size of the protein was approximately about $30 \mathrm{kDa}$ (Krishnamurthy, 2006).

\section{PCR based cloning}

The ToLCV-CP gene was PCR amplified using designed TOLCV-CP (forward) - 5, ATC GGA TCC TCC AAA ACT GAA GCG GTT 3' and ToLCV-CP (reverse) - 5' ATT AAG CTT GTT GCG CAT ACC CAG GAG AG 3' primers. An 786 bp product from ToLCV cDNA which included the full cds of ToLCV-CP gene was amplified using the specific primers of ToLCV-CP with restriction sites and spacer nucleotides (Fig. 1). Amplification of nearly similar length of fragment was reported by Sengoda et al., (2012). Reddy, (2006), characterized ToLCV from different regions of Northern Karnataka reported the presence of amplicons of $1000 \mathrm{bp}$ with an ORF of $771 \mathrm{bp}$. Krishnamurthy, 2006 also reported the presence of amplicons of approximately $1000 \mathrm{bp}$ when performed PCR with DNA samples from ToLCV infected tomato leaf samples.

The reason for getting extra $b p$ in amplification was because of addition of restriction sites and spacer nucleotides in the forward and reverse primers of ToLCV-CP. Further, the ToLCV-CP gene was cloned in to T/A cloning vector $\mathrm{pTZ}$ 57R/T. The bulk PCR was done and then sharp amplicon (ToLCV$\mathrm{CP}$ gene) of the expected size (786 bp) was eluted from the gel, which was then cloned into pTZ57R/T and named as pTHMN15 (Fig. 2 ). This construct was transferred into $E$. coli DH5 $\alpha$ and transformants were confirmed by colony PCR (Fig. 3) and restriction digestion analysis using BamHI and SalI restriction endonucleases giving rise to linear fragment of $786 \mathrm{bp}$ insert and $2.8 \mathrm{~kb}$ vector back bone (Fig. 4).

The construct pTHMN15 containing ToLCV$\mathrm{CP}$ gene was sequenced by employing M13 universal primers. The complete nucleotide sequence of ToLCV-CP gene is shown in Figure 5. The available sequence information from cloned fragments was analyzed using BLAST algorithm available at http://www.ncbi.nih.gov. The nucleotide sequence of CP of ToLCV isolate had 94 per cent homology with CP gene of Iranian isolate reported by Behjatnia et al., (2004). 86 to 88 per cent homology was found with $\mathrm{CP}$ gene sequences of ToLCV isolates from Bangalore (Karnataka), Tamil Nadu and Rajasthan.

Sub cloning of TOLCV-CP gene in prokaryotic expression vector

ToLCV-CP gene was amplified in the cloning vector pTZ57R/T and then cloned into BamHI and SalI sites of the expression vector pQE30 and transformed into E. coli JM109 cell which is a maintenance host for plasmid. The transformants with ToLCV-CP were picked on Luria agar plates containing $A \mathrm{mp}_{100}$ and $\mathrm{Nal}_{10}$ selection pressure. The recombinants obtained were again confirmed by colony PCR (Fig. 6) and by restriction digestion with BamHI and SalI. It was observed that linearization of vector and release of fragment (786 bp) on agarose gel electrophoresis (Fig. 7). Later, the plasmid from the confirmed recombinant clones in E. coli JM109 cells was transformed in to expression host $E$. coli M15 (pREP4) for pQE30. The recombinant clone pTHMN30 (Fig. 8) was obtained. 
Fig.1 PCR confirmation of infected sample

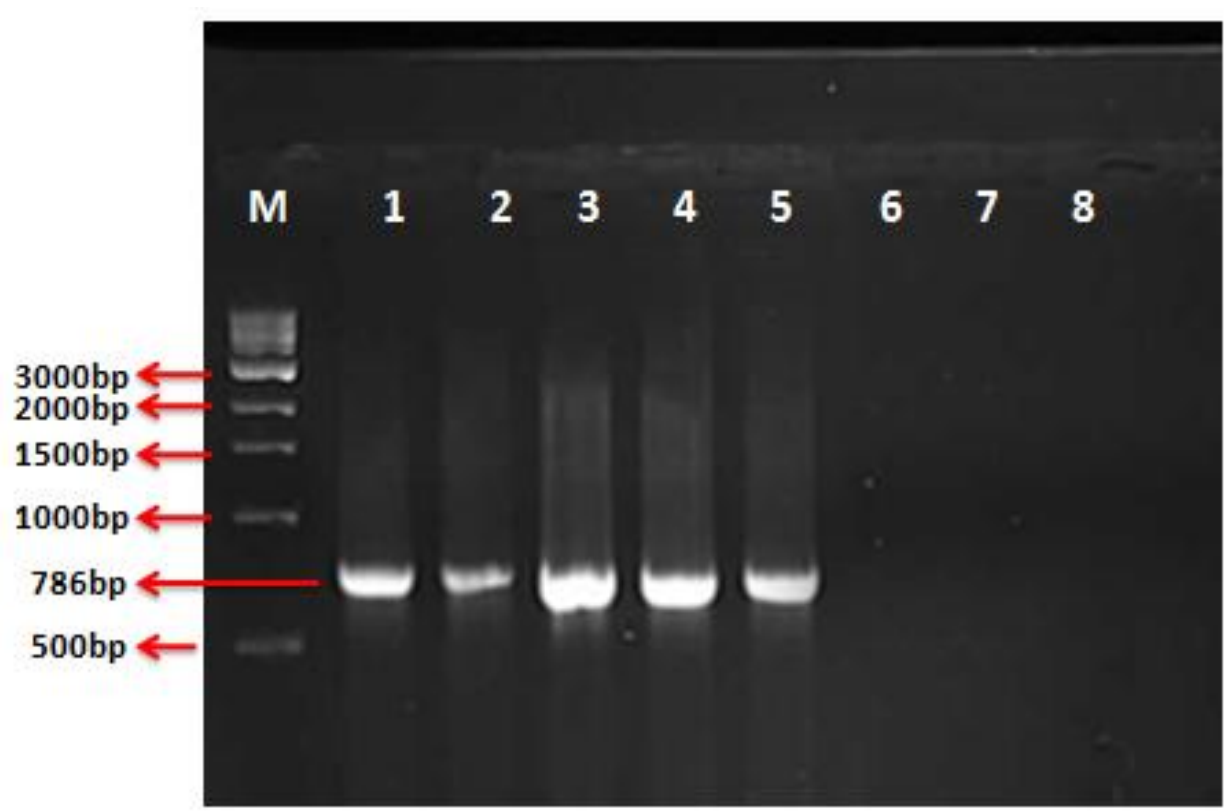

(Lane 1: Marker, Lanes 1, 2, 3, 4, 5: Infected samples, Lanes 6, 7, 8: Healthy samples)

Fig.2 Construct map of pTHMN15 containing full length ToLCV-CP in pTZ57R/T

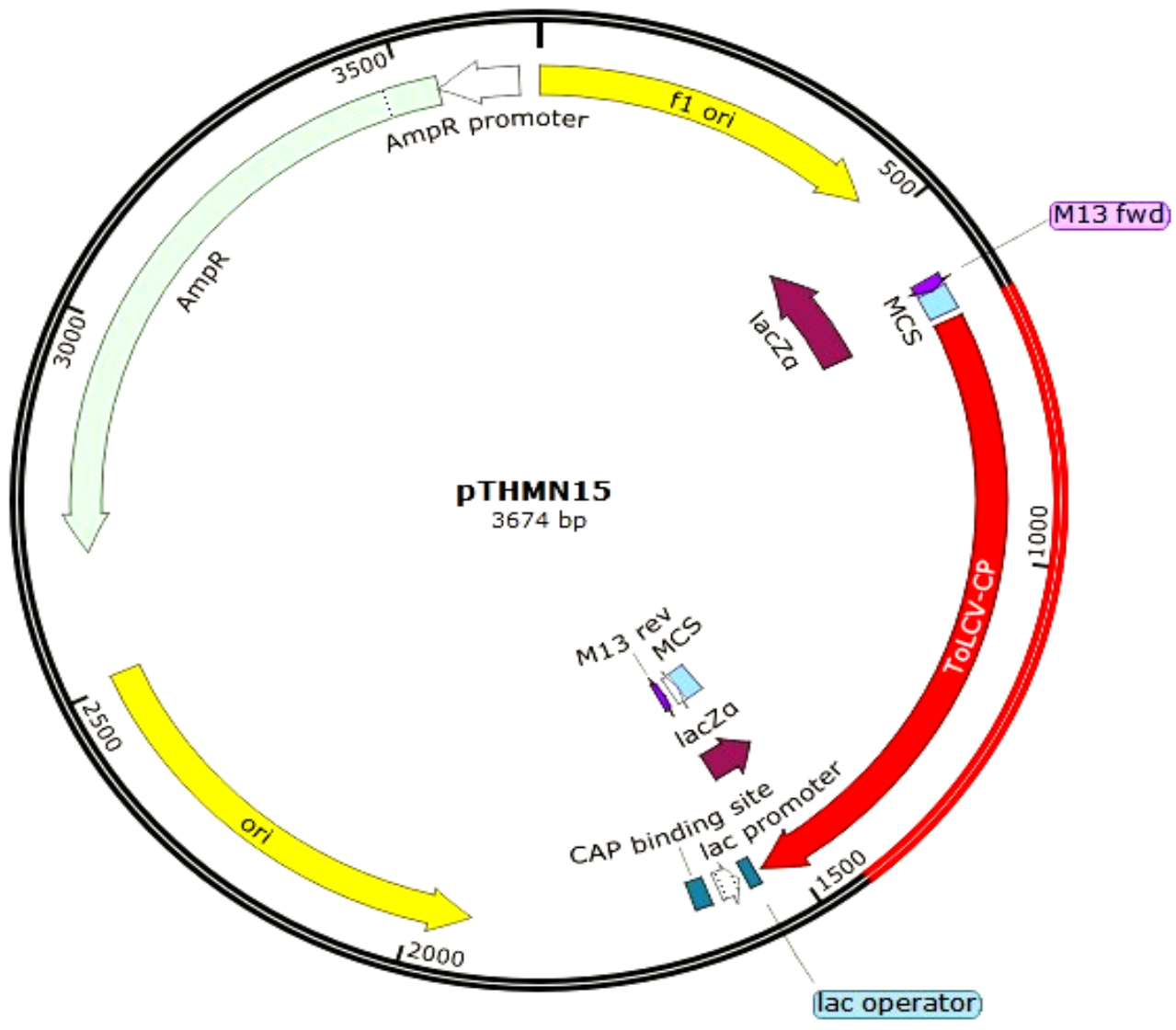


Fig.3 Colony PCR confirmation of ToLCV - CP gene in pTZ57R/T

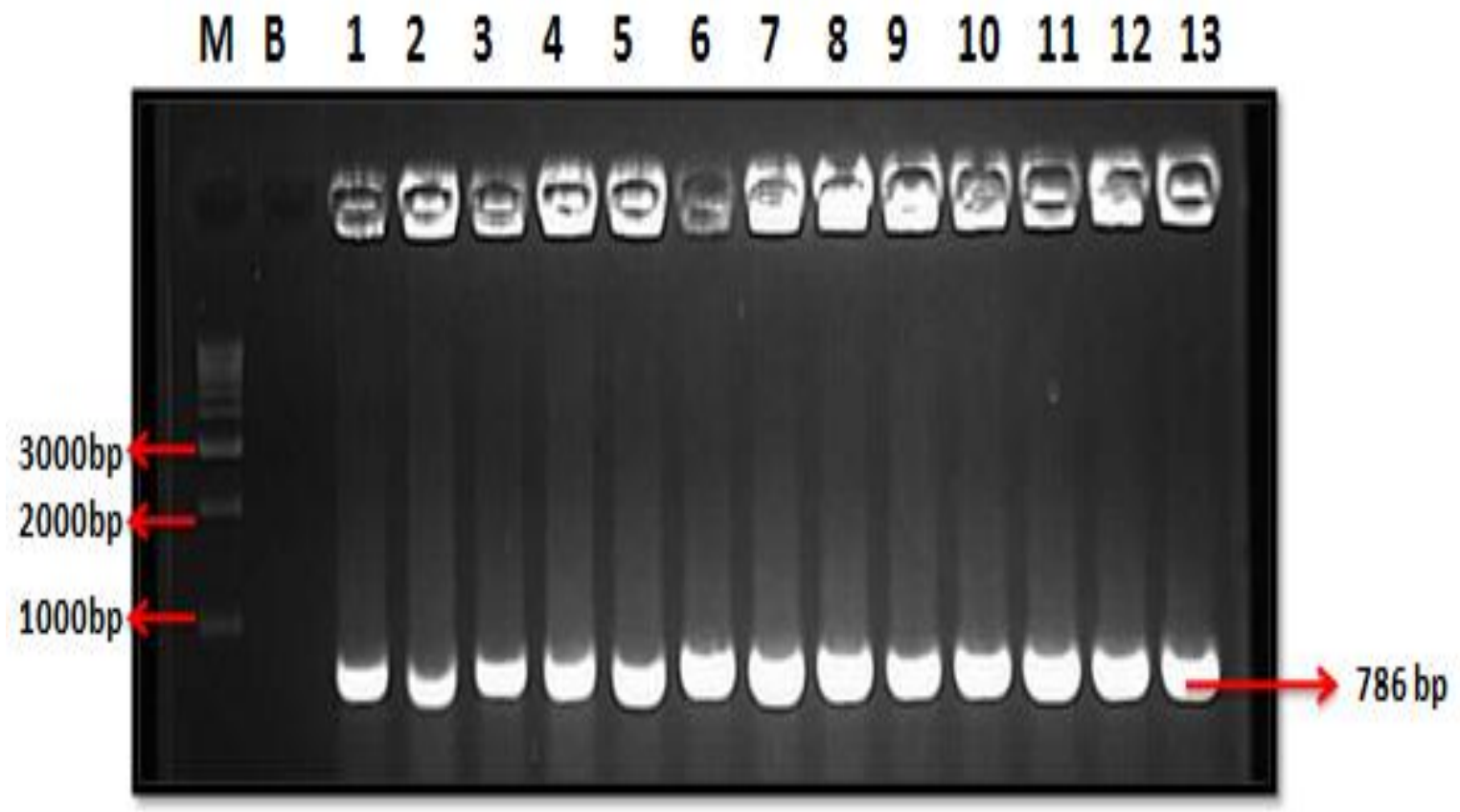

(Lane 1: Marker, Lane B: Blank, Lanes 1-13: PCR amplification of ToLCV-CP gene from recombinant clones)

Fig.4 Restriction confirmation of TOLCV-CP clones in pTZ57R/T with BamHI and SalI

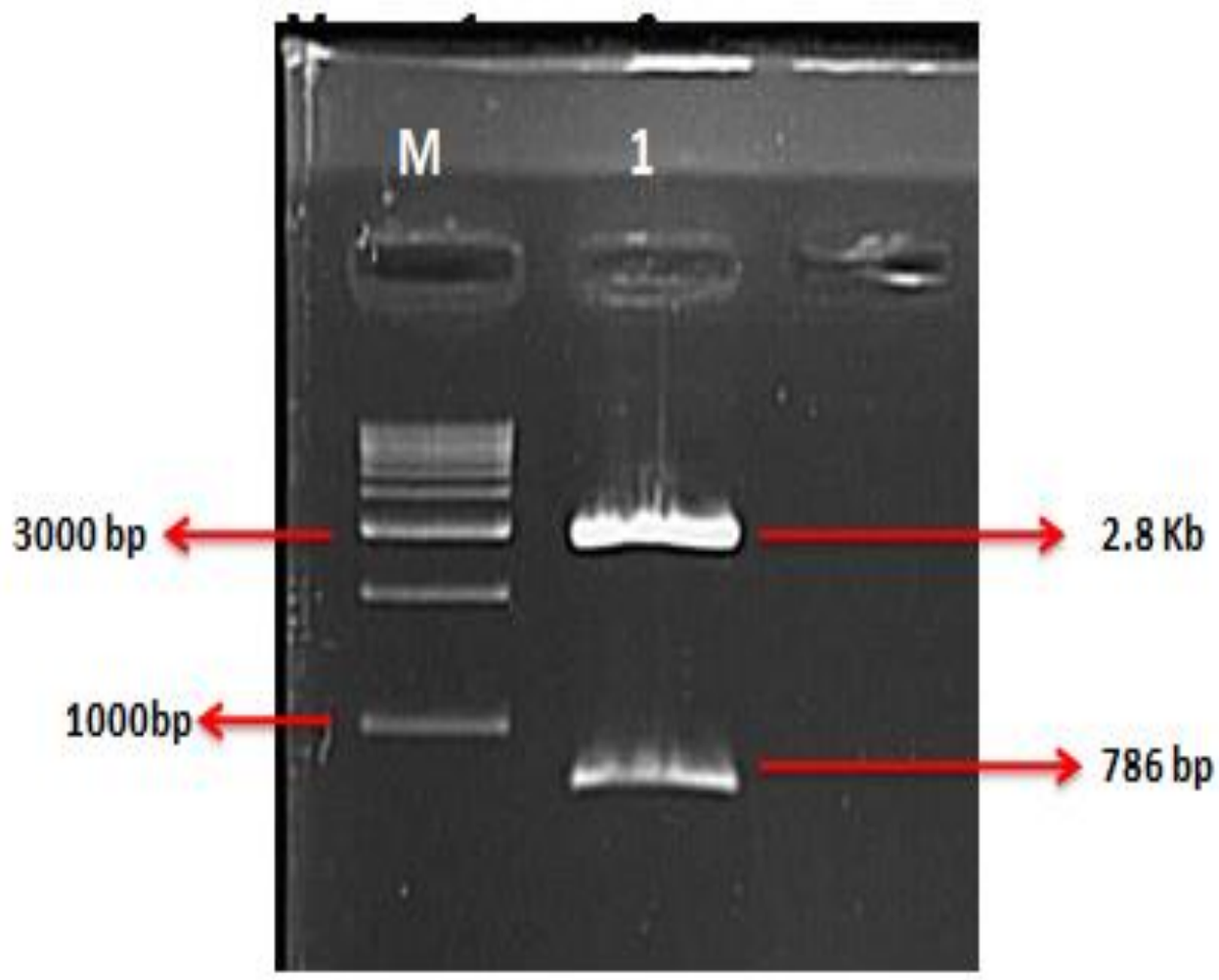

(Lane M: Marker, Lane 1: Restriction Digestion with BamHI and SalI) 
Fig.5 Complete amino acid and nucleotide sequence of ToLCV-CP from pTHMN15

Met Ser Lys Arg Pro Ala Asp Met Ile Ile Ser Gly Pro Val Ser

1 ATG TCC AAG CGT CCG GCA GAT ATG ATC ATT TCC GGG CCC GTC TCG

Lys Tyr Arg Arg Leu Ser Glu Ser Ile Ser Pro Tyr Ser Lys Arg

46 AAG TAT CGC CGA CTT TCT GAG TCA ATC AGC CCA TAC AGC AAG CGT

Ala Ala Val Arg Ile Val Arg Gly Thr Lys Gly Lys Glu Met Gly

91 GCT GCT GTC CGC ATT GTC CGC GGC ACA AAG GGA AAG GAA ATG GGC

Asn Arg Pro Met Arg Lys Pro Met Phe Tyr Arg Met Tyr Arg Gly

136 AAC AGG CCC ATG CGG AAG CCC ATG TTT TAC AGG ATG TAC AGA GGT

Pro Asp Val Pro Lys Gly Cys Glu Gly Pro Cys Lys Val Gln ser

181 CCT GAT GTT CCC AAG GGA TGT GAA GGC CCA TGT AAG GTC CAA TCT

Phe Asp Ala Lys Asn Asp Ile Gly His Met Gly Lys Val Ile Cys

226 TTC GAT GCT AAG AAC GAT ATT GGT CAT ATG GGT AAG GTT ATA TGT

Leu Ser Asp Val Thr Arg Gly Met Gly Leu Thr His Arg Val Gly

271 TTG TCT GAT GTC ACG AGG GGA ATG GGA TTG ACC CAT CGA GTA GGG

Lys Arg Phe Cys Val Lys Ser Leu Try Phe Val Gly Lys Ile Trp

316 AAA CGT TTC TGT GTG AAG TCT TTG TAT TTT GTC GGC AAG ATT TGG

Met Asp Glu Asn Ile Lys Thr Lys Asn His Thr Asn Thr Val Leu

361 ATG GAC GAG AAC ATC AAG ACC AAG AAC CAT ACT AAC ACT GTT TTG

Phe Trp Ile Val Arg Asp Arg Arg Pro Thr Gly Thr Pro Asn Asp

406 TTC TGG ATT GTG AGA GAC AGG CGT CCT ACA GGA ACC CCA AAT GAT

Phe Gln Gln Val Phe Asn Val Tyr Asp Asn Glu Pro Ser Thr Ala

451 TTC CAA CAA GTG TTC AAT GTT TAT GAT ASN GAG CTT TCT ACG GCT

Thr Val Lys Asn Asp Gln Arg Asp Arg Phe Gln Val Leu Arg Arg 496 ACT GTG AAG AAG GAC CAG CGT GAT CGT TTT CAG GTG CTG AGG AGG

Phe Gln Ala Thr Val Thr Gly Gly Gln Tyr Ala Ala Lys Glu Gln

541 TTT CAA GCA ACA GTC ACA GGT GGT CAA TAT GCT GCT AAG GAA CAA

Ala Ile Ile Arg Lys phe Tyr Arg Val Asn Asn Tyr Val Val Tyr

586 GCT ATA ATT AGG AAG TTC TAT CGT GTT AAT AAT TAT GTG GTT TAT

Asn His Gln Glu Ala Gly Lys Tyr Glu Asn His Thr Glu Asn Ala

631 AAT CAT CAA GAA GCT GGG AAG TAT GAG AAT CAC ACT GAG AAT GCT

Leu Leu Leu Tyr Met Ala Cys Thr His Ala Ser Asn Pro Val Tyr

676 TTG TTG TTG TAT ATG GCA TGT ACT CAT GCC TCT AAC CCC GTC TAT

Ala Thr Leu Lys Val Tyr Arg Ser Tyr Phe Tyr Asp Ser Val Thr

721 GCT ACT TTG AAA GTT GAT AGG AGT TAC TTC TAC GAT TCT GTA ACC

Asn $* \star \star$

766 AAT TAA 
Fig.6 Colony PCR confirmation of ToLCV-CP gene in pQE30

\section{M $1223 \quad 45667891011121314$}

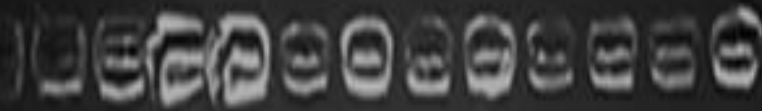

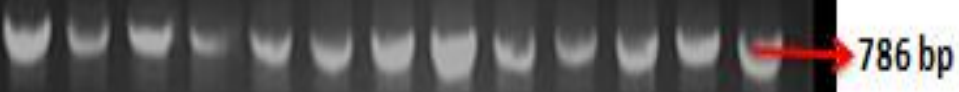

(Lane 1: Marker, Lane B: Blank, Lanes 1-13: PCR amplification of ToLCV-CP gene from recombinant clones)

Fig.7 Restriction confirmation of ToLCV-CP clones in E. coli M15 (pREP4)

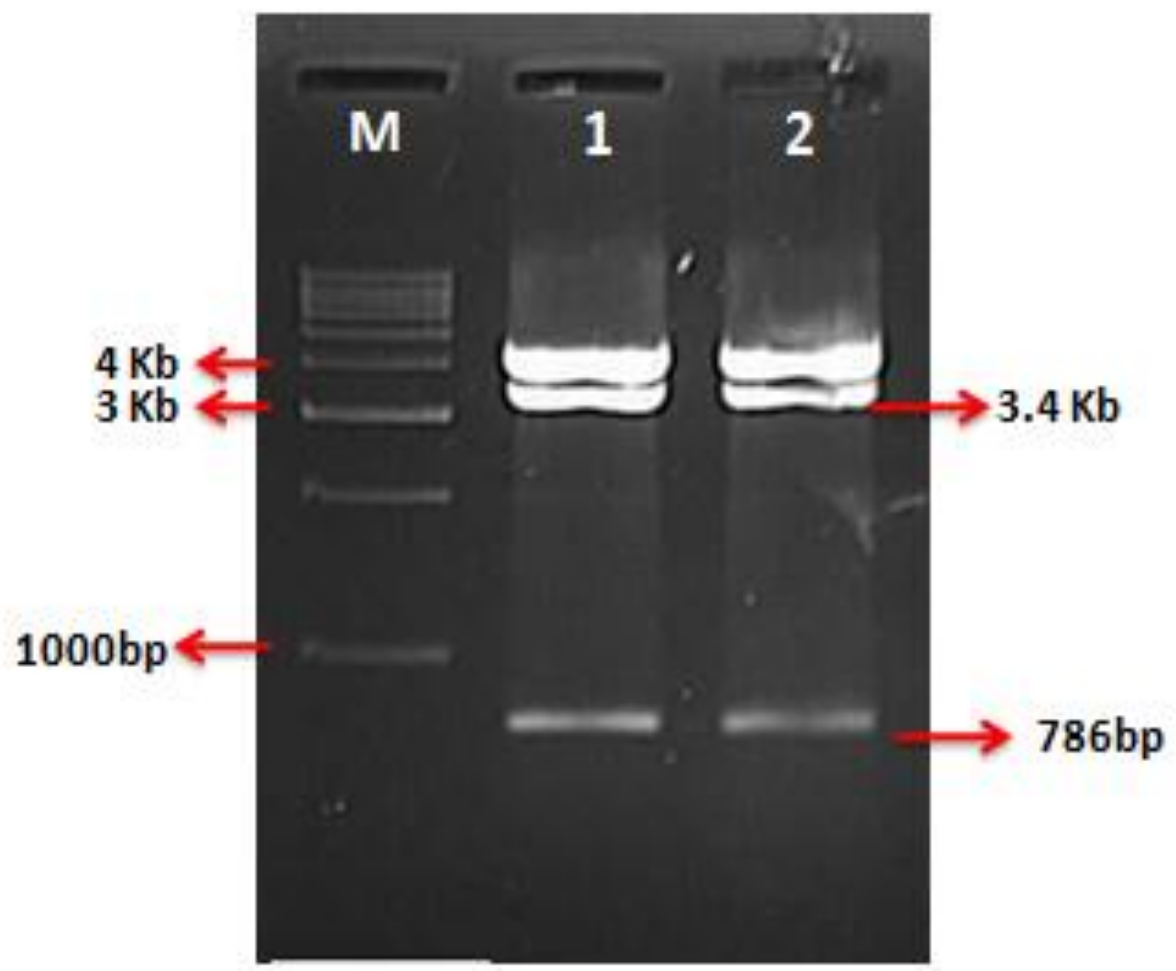

(Lane M: Marker, Lanes 1, 2 : Restriction Digestion with BamHI and SalI) 
Fig.8 Construct map of pTHMN30 containing full length TOLCV-CP gene in pQE30

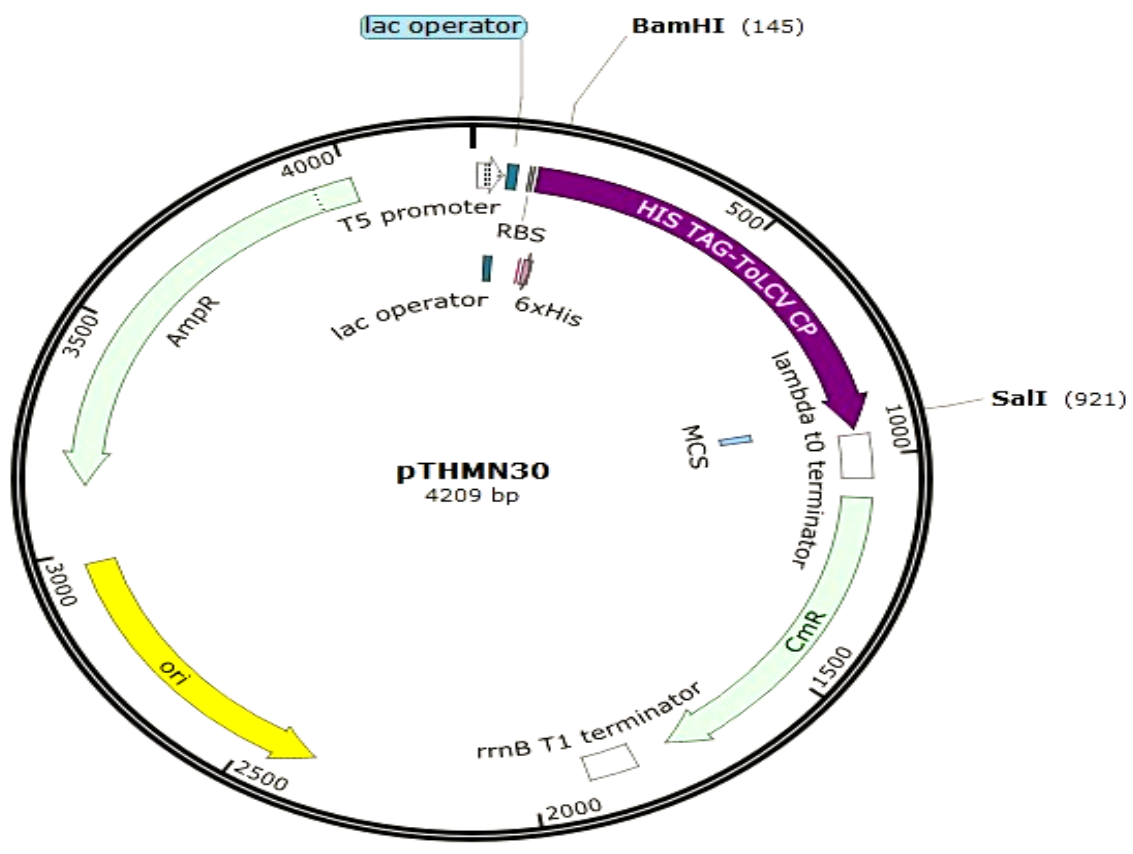

Fig.9 SDS-PAGE analysis of TOLCV-CP and purified fusion protein after His-Tag purification

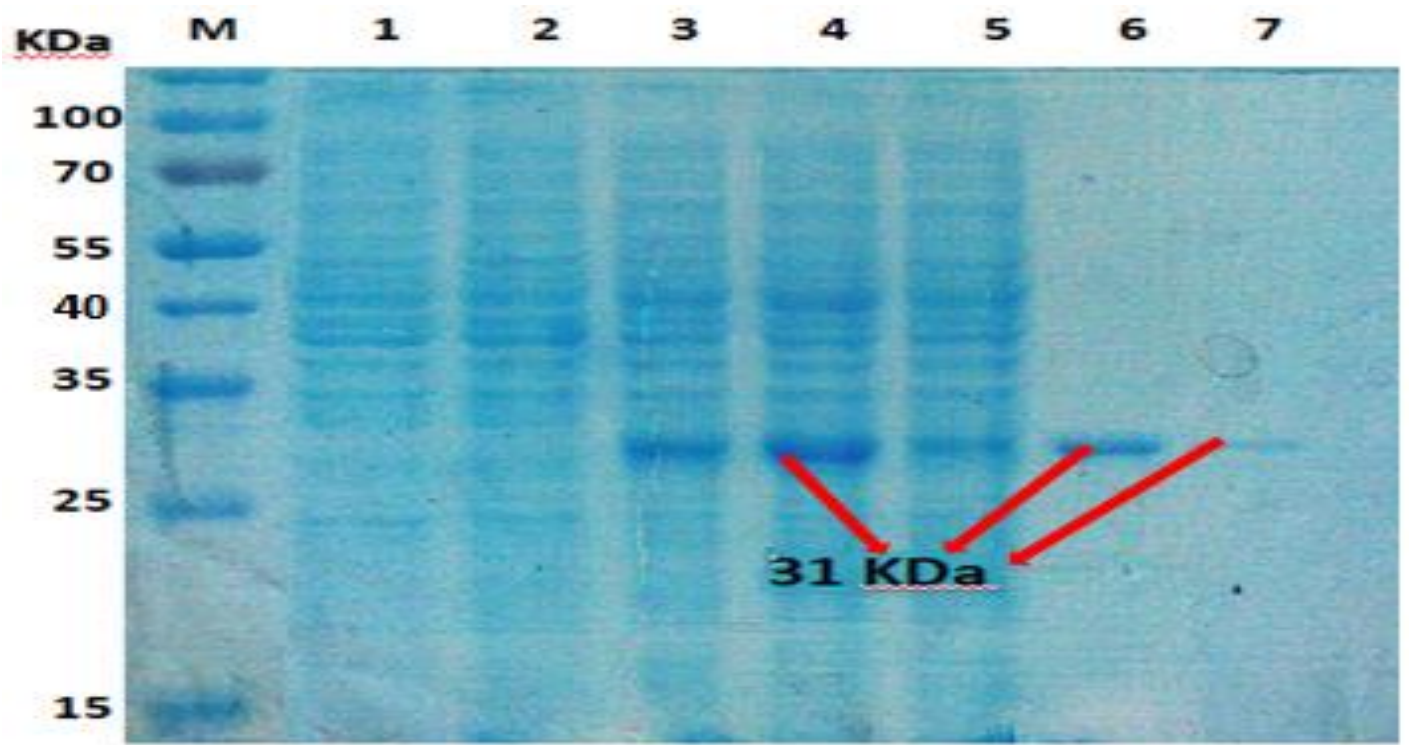

(Lane M: Prestained protein ladder, Lanes 1, 2: Uninduced sample, Lanes 3, 4, 5: Induced sample, Lane 6: His-tag purified Elute 1, Lane 7: His-tag purified Elute 2)

Expression studies in $E$. coli

After checking the precision of the clones, the recombinant clone pTHMN30 was subjected to expression. The cells were induced by using 1mM IPTG for different time period (3hr, $5 \mathrm{hr}$ and $7 \mathrm{hr}$ ) with $1 \mathrm{hr}$ time gap. The expressed protein was analyzed on SDSPAGE. A protein band of approximately 31 kDa was observed (Fig. 9). It was found that 
at $1 \mathrm{mM}$ of IPTG concentration at $37{ }^{0} \mathrm{C}$ for 3 hr showed better expression of CP. However, Devaraja et al., (2004) cloned CP gene of ToLCBV-(Ban-5) into pQE-30 expression vector. The cloning strategy resulted in the addition of 18 non-viral amino acids (including six histidines at the $\mathrm{N}$ terminus of $\mathrm{CP})$. The expression of recombinant $\mathrm{CP}$ was induced by addition of IPTG to a final concentration of $1 \mathrm{mM}$ at $37{ }^{0} \mathrm{C}$ for $4 \mathrm{hr}$. Expressed fusion proteins were easily purified from bacterial lysates by affinity chromatography using Ni-NTA resin. Similarly, Krishnamurthy, (2010) cloned ToLCV coat protein gene into prokaryotic expression vector $\mathrm{pET} 28 \mathrm{a}$.

The clone was transformed into E. coli BL21, induced by IPTG to produce the target protein. Size of the protein was approximately about $30 \mathrm{kDa}$.

Thus, it is suggested that individual standardization is required based on the vector and the promoter in the vector. Long time induction resulted in degradation of coat protein.

Subsequently the expressed protein was purified using Genei His-tag purification kit and the purified protein was analysed on 12 per cent SDS-PAGE. After purification, single band of $31 \mathrm{kDa}$ was observed (Fig. 9). Further the final yield of expressed protein was estimated using Lowry's method of protein estimation. Three hours of induction period yield corresponded to nearly 1.34 $\mathrm{mg} / 100 \mathrm{ml}$ of culture.

The present investigation was carried out to clone and express the recombinant coat protein gene of Tomato leaf curl virus in $E$. coli. An expected band size of $31 \mathrm{kDa}$ was observed in the clones which indicated the successful expression of ToLCV coat protein gene.
Further, this purified ToLCV coat protein can be used as an antigen to develop monoclonal antibodies using phage display technology.

\section{References}

Behjatnia, A., Izadpanah, K., Dry, I. B. and Rezaian, A., 2004, Molecular characterization and taxonomic position of the Iranian isolate of Tomato leaf curl virus. Iran. J. Plant Pathol. 40, 7794.

Brown, J. K., Fauquet, C. M., Briddon, R.W., Zerbini, M., Moriones, E. and NavasCastillo J, 2012, Virus taxonomy: classification and nomenclature of viruses: Ninth Report of the International Committee on Taxonomy of Viruses. In: King AMQ, Adams MJ, Carstens EB, Lefkowitz EJ (eds), Part II-single stranded DNA viruses. Elsevier, 359-373.

Devaraja., Pradnya, G., Sunitha, S. N., Kirthi, N., Anjali, K., Muniyappa, V. and Savithri, H. S, 2004, Production of monoclonal antibodies to Tomato leaf curl Bangalore virus, Ann. appl. Biol., 144: 333-338.

Inoue-Nagata, A. K., Lima, M. F. and Gilbertson, R. L., 2016, A review of geminivirus (begomovirus) diseases in vegetables and other crops in Brazil: current status and approaches for management. Hortic. Bras., 34: 008018.

Krishnamurthy, K., 2006, PostTranscriptional Gene Silencing (PTGS) of Tomato Leaf Curl Virus (ToLCV) in Tomato. Ph. D. Thesis, Univ. Agric. Sci., Dharwad, Karnataka (India).

Reddy, B. A., 2006, Molecular characterization, epidemiology and management of Tomato leaf curl virus (ToLCV) in Northern Karnataka. Ph. D. Thesis, Univ. Agric. Sci., Dharwad (India). 
Reddy, B. A., Patil, M. S., Reddy, M. K. and Rajashekaram, T., 2010, Molecular detection, survey and management of tomato leaf curl virus in northen Karnataka. J. Mycol. Plant Pathol., 40(2): 207-212.

Sambrook, J. and Russel, D. W., 2001, Molecular Cloning: A laboratory Manual, $3^{\text {rd }}$ Edn., Cold Spring Harbor Laboratory, New York. 40: 47.

Sengoda, V. G., Wen-Shi, T., Robert, C., de la Pen., Sylvia K. G., Lawrence, K. and
Hughes, J. 2012, Expression of the fulllength coat protein gene of tomato leaf curl taiwan virus is not necessary for recovery phenotype in transgenic tomato. J. Phytopathol., 160: 213-219

Solieman, T.H., El-Gabry, M.A.H. and Abido, A.I., 2013, Heterosis, potence ratio and correlation of some important characters in tomato (Solanum lycopersicum L.). J. Plant Pathol., 150: 25-30.

\section{How to cite this article:}

Honnesh, S.H., M.S. Patil, Narayan Moger, V.P. Savalgi, L.S. Rashmi and Ratna Bergi. 2018. Cloning and Expression of Tomato Leaf Curl Virus Coat Protein Gene in E. coli. Int.J.Curr.Microbiol.App.Sci. 7(04): 141-151. doi: https://doi.org/10.20546/ijcmas.2018.704.016 